\title{
En busca del ADN de la escritura en Historia de una absolución familiar de Germán Marín
}

\author{
In search of the DNA of the writing in Historia de una \\ absolución familiar by Germán Marín
}

Mariela Fuentes Leal

Universidad de Concepción. Concepción, Chile.

mariefue@gmail.com

\section{RESUMEN}

Entendemos la escritura en Historia de una absolución familiar de Germán Marín como una metáfora de la espiral del $\mathrm{ADN}$, en tanto reflexión sobre sí misma en busca de su origen y línea de fuga del discurso literario hacia la vida del propio autor y en cuya propuesta narrativa se concatenan la imaginación y la memoria.

Palabras claves: Marín, ADN, escritura, imaginación, memoria.

\begin{abstract}
We understand the writing in Historia de una absolución familiar by Germán Marín as a metaphor of the DNA spiral, while the reflection about itself in search of its origin and the escape line of the literary speech towards the life of the author himself and in whose narrative proposal the imagination and memory link each other.
\end{abstract}

Keywords: Marín, DNA, writing, imagination, memory.

Recibido: 20-09-2010. Aceptado: 20-10-2010.

*Este artículo forma parte de la tesis de Doctorado en Literatura Latinoamericana (Universidad de Concepción), en desarrollo, "En busca del ADN de la escritura, de la estirpe y de la cultura chileno-italiana en Historia de una absolución familiar de Germán Marín”, financiada y apoyada por la Comisión Nacional de Investigación Científica y Tecnológica, Conicyt. 


\section{INTRODUCCIÓN}

El mundo es el manuscrito de otro mundo inaccesible a una lectura universal y que sólo la existencia descifra.

(Jaspers)

A nalizamos la trilogía Historia de una absolución familiar de Germán Marín, compuesta por las novelas Círculo vicioso (1994), Las cien águilas (1997) y La ola muerta (2005), en un contexto teórico "posmediático", de acuerdo a la visión de Guattari (1996), en el cual se establece un nuevo estado del arte y, específicamente, de la literatura, la que se convierte en una reflexión sobre la génesis de la escritura, que le lleva a un doble proceso: por una parte, a reflexionar sobre sí misma y, por otra, a desplazarse hacia otras dimensiones del conocimiento ${ }^{1}$. Por esto, proponemos como hipótesis que el proyecto de escritura del narrador chileno se plantea como una búsqueda metafórica del $\mathrm{ADN}$ de la escritura, que reflexiona sobre el lenguaje cuya intransitividad lo retorna a su origen constituyente y, a la vez, lo desterritorializa de la lengua mayor.

De esta manera, en primer lugar, nos situamos en el contexto mayor de las transformaciones experimentadas por la Humanidad en los dos últimos siglos. En efecto, desde fines del siglo XIX, el desarrollo exponencial de la tecnología ha generado cambios fundamentales en la configuración espaciotemporal de las sociedades. Cabe mencionar, dos guerras mundiales y múltiples conflictos bélicos menores que, entre otras consecuencias, terminan con los grandes "metarrelatos", según Lyotard (1984); entre ellos, el proyecto de la Ilustración que propagaba la idea de una racionalidad intrínseca en el ser humano.

En segundo lugar, pensamos en el caso específico de la literatura tradicional; es decir, un discurso ficcional inscrito en el arte como una de las bellas artes, el que durante el siglo XX entra en crisis como proyecto lineal y totalizador, y se convierte en un despliegue de pequeños relatos, movidos a una velocidad infinita, con flujos discontinuos y reconexiones en distintos puntos. El proceso de escritura se complejiza y la literatura deviene en una reflexión sobre sí misma y, al mismo tiempo, se desplaza hacia otras áreas, fuera del espacio literario. De este modo, algunas obras literarias permiten investigaciones transdisciplinarias, perdiendo su carácter ficticio exclusivo Hdaf.

En adelante, la trilogía Historia de una absolución familiar será abreviada con las iniciales 
para convertirse en documentos críticos y experimentales a través de los cuales se accede, desde una mirada subjetiva, a un conocimiento ecléctico que presenta distintas dimensiones de la realidad. En este contexto, rescatamos algunos postulados teóricos sobre la noción de la literatura a través de la historia. Por ejemplo, el de Todorov (1987), quien plantea que la noción de literatura se transforma con el paso del tiempo, por lo cual los conceptos del pasado no serían pertinentes en otras épocas. También, los planteamientos de Blanchot en los libros El espacio literario (1992a) y El libro que vendrá (1992b) y La escritura del desastre (1990) destacan el carácter nómade e interrogativo de la literatura cuya experiencia reflexiva se asemeja a una espiral de paradojas que arrastra al escritor hacia la ausencia del tiempo histórico. Asimismo, Foucault relaciona la noción de literatura con la idea de la intransitividad radical y realiza un análisis complejo entre los términos lenguaje, obra y literatura en su libro De lenguaje y literatura (1996), donde propone que la palabra esparcida se recurva sobre sí misma y se convierte en silenciosa, estableciendo una conexión con Blanchot, en tanto la escritura surge en el silencio. De este modo, las ideas anteriores se relacionan con algunos de los conceptos postestructuralistas; por ejemplo, con los de Deleuze y Guattari de literatura menor (1990), desterritorialización (1990) y rizoma (1997), que convergen en la idea del desplazamiento de la literatura hacia un espacio abierto, donde puede circular la materia narrada con un uso menor del lenguaje a través del cual los problemas individuales del escritor se convierten en políticos y adquieren un valor colectivo. De esta forma, a medida que el mundo ha devenido caos, el libro-raíz, de forma arbórea y jerárquica, ha devenido en el libro-rizoma constituido por múltiples entradas y salidas ramificadas, mediante fragmentos autónomos (mesetas), que pueden ponerse en relación con cualquier otro punto del libro al ser puntos de intersección en diversos campos (cuerpos, geográficos, imágenes, mensajes, entre otros); rizoma que descentraliza al lenguaje hacia otras dimensiones y registros.

En tercer lugar, nuestra base teórica se relaciona de forma específica con el pensamiento de Félix Guattari, quien propone un cambio de posición del arte en su ensayo "El nuevo paradigma estético" (1995), en tanto está desligado de las referencias ideológicas y verdades trascendentales; así la actividad artística "es una tensión por apresar la potencialidad creativa que se encuentra en la raíz de la finitud sensible" (Guattari, 1995: 199). Entonces, la manera de capturar la creación literaria sería, de acuerdo al Nuevo Paradigma Estético Procesual, comprender la escritura como un proceso permutable enfocado en la investigación sobre su origen y en la reflexión respecto 
a la tarea de escribir.

Efectivamente, podemos comprobar que el escritor Germán Marín evidencia los procesos narrativos a través de los cuales la literatura se rehace continuamente y crea ficción. Por una parte, para averiguar por qué lo hace, sabiendo que no hay respuesta, como él mismo lo ha afirmado en una entrevista a Daniel Osorio: "Escribo para averiguar por qué escribo, sabiendo que no hay respuesta” (Osorio, 1997: 44). Así, tal vez, la responsabilidad del escritor arranca de la propia obra y, en una suerte de círculo, termina por volver a ella. En palabras de Marín, en otra entrevista: "Hay veces en que la literatura sólo se remite a sí misma, sin que por ello abandone el mundo" (El Mercurio, 1999: 15). Por la misma razón, Marín declara cuando recibe el Premio Atenea, en la Universidad de Concepción, en noviembre de 2008: "La literatura de creación está en peligro y sólo se salvará de los excesos del sistema si es fiel a sí misma" (Marín, 2008). Por otra parte, Marín construye una creación literaria que escapa a los géneros literarios tradicionales y provoca un estado de tensión hacia el afuera de la literatura, para experimentar diversas formas creativas, mediante flujos que le llevan a relacionarse con otras disciplinas, como la filosofía, la lingüística, la historia y la antropología. En relación a lo anterior, algunas aproximaciones periodísticas y, en una mínima medida, desde la crítica académica han reconocido una escritura compleja que requiere de lectores con un gran acervo cultural y literario. Por ejemplo, Patricia Espinosa afirma respecto a Las cien águilas: "estamos frente a un tipo de literatura sobrecodificada y sobre 'decodificada', ya que casi se lee ella misma" (Espinosa, 1997: 34). Más adelante, en su reseña, Espinosa agrega: "una obra intervenida desde múltiples voces... la palabra de Marín desborda citas bibliográficas, cinematográficas, musicales, semánticas o literarias, a la par que registra todo tipo de elementos propios de la cultura del pastiche y, finalmente, el discurso que entremezcla el dolor del exilio, la nostalgia por el pasado y la conciencia del acto de escritura" (Espinosa, 1997: 34). Por su parte, el crítico Filebo, del diario Las Últimas Noticias, señala que la novela Círculo vicioso es fruto de una prolongada lección de crítica y autocrítica y él mismo reconoce: "haber hecho mil rodeos en torno al libro antes de encarnarnos con su materia, que, por de pronto, no es una sola" (Filebo, 1995: 14). Por su parte, Camilo Marks señala: "es una obra para lectores exigentes e informados, pero los demás, con algo de empeño, también deberán y podrán disfrutarla” (Marks, 1996: 3).

Así también, las aproximaciones críticas a la literatura de Germán Marín destacan, tanto la posibilidad de indagar, a través de un ejercicio de memoria autorreferente, en un pasado familiar, cultural y social, como la de 
crear una especie de confesión trabajada a través del juego entre verdad y ficción cuando narra acontecimientos biográficos tanto de la vida privada como pública. En palabras del propio autor en la entrevista a Daniel Osorio, leemos: "hay un intento de radiar, de crear círculos concéntricos de esta visión vuelta hacia atrás, de rodearla, de mortificarla, de cruzarla, de someterla, de aprisionarla, lo que es difícil" (Osorio, 1997: 44). Del tal forma, el autor presenta una novela en construcción que trabaja la experimentación narrativa y plantea diversos cuestionamientos, una revisión de los valores, incertidumbre de la historia y lo literario originada por la crisis personal de valores provocada por el golpe militar de 1973. Esta afirmación se relaciona con la idea de Patricia Espinosa, quien, significativamente, rescata la postura teórica de Marín en su novela, ya que "exhibe una estrategia ficcional basada en claros presupuestos posestructuralistas, con lo cual transgrede el implícito carácter decimonónico de realizar la gran historia de una familia" (Espinosa, 1997: 34).

A lo anterior, Javier Edwards Renard agrega: "La escritura de este autor no es sólo una interpretación de una historia individual o de la política o social chilena, sino también, un ensayo literario, una profunda y vital reflexión sobre el ejercicio de narrar" (Edwards Renard, 1997: 3). Desde este punto de vista, Germán Marín, en su trilogía Hdaf, utiliza el concepto de "escribiviente", cuyo rasgo fundamental es la fusión de escritura y vida, a través de procedimientos narrativos, que mezclan ficción y realidad, los cuales originan un juego literario entrecruzado, donde, por ejemplo, en Las cien águilas, según Patricia Espinosa:

No hay un proceso totalmente acabado antes de la novela, ya que ésta se va armando poco a poco en un acto mismo de su escritura y de su vida. Un proceso que no concluye, aun cuando podamos verla como una obra ya finalizada...desde esta perspectiva podría considerarse que pasar por lo militar constituye un duro proceso de iniciación, necesario para luego acceder al arte (Espinosa, 1997: 34).

De esta manera, los polos de realidad y ficción son conceptos relativos desde el punto de vista del ejercicio literario en la narrativa de Marín, ya que se trata de llevar el discurso literario a otros terrenos. De tal forma que la trilogía $H d a f$ problematiza la novela como género y quizás hasta el sentido cuando incorpora una mixtura de géneros literarios: libro, novela de memorias, ensayo, crónica, diario, testimonio, etc., que permite configurar una cartografía lúdica de su literatura, estableciendo, según Rodrigo Pinto 
en una reseña sobre La ola muerta: "múltiples juegos y diversos niveles de escritura y de lectura" (Pinto, 2006: 7). Por su parte, Marín señala no creer en la división de géneros literarios, en tanto: "siento que ficción y ensayo están llenos de vasos comunicantes. Lo imaginario también es real. Por eso, todos estos recursos formales son juegos de espejos que me permiten la introspección” (Rivera, 1997: 32). Así, creemos, el tema del doble ocupará un lugar fundamental en esta tendencia a objetos simbólicos como el espejo. Es más, Marín piensa que en su trabajo narrativo "todo forma parte de una misma escritura, de una misma mano, si nos ponemos extremos. Creo que en mi literatura hay vasos comunicantes entre un libro y otro" (Matus 2007: E16-E17).

Por lo expuesto, desde la complejidad detectada por la crítica y por nuestras propias investigaciones sobre la narrativa de Germán Marín, profundizamos en esa complejidad en términos teóricos y postulamos la posibilidad de un acercamiento transdisciplinario a la narrativa mariniana y leemos su trilogía Hdaf desde una noción de la genética: $\mathrm{ADN}^{2}$.

\section{CARTOGRAFÍA DE LA MONA LISA DE LA CIENCIA: ADN}

Detectamos una primera relación entre el $\mathrm{ADN}$ y los estudios críticos y literarios en la serie de ensayos que George Steiner recoge en su libro Extraterritorial (2000), una publicación de inicios de la década del setenta del siglo XX y en el que adelanta nociones que serán desarrolladas, por ejemplo, por la teoría literaria postestructuralista. En efecto, en el último capítulo, "Líneas de vida", Steiner señala cómo el lenguaje complejo de las ciencias exactas pasa a ser parte de la vida académica y del lenguaje cotidiano y, de manera muy interesante, relaciona esta situación con la crisis de la literatura:

No sólo la doble hélice del ADN entró a integrar nuestro repertorio de referencias comunes. Una historia de la fraseología y los sinónimos de los últimos años registraría que conceptos como "información", "codificación", "sistema de vida" y "ambiente" han pasado del uso especializado y matemáticamente formalizado al lenguaje cotidiano. El hecho de que la física de Newton encontró su expresión literaria en la poesía de Pope mientras los cambios científicos actuales tienen su eco imaginario en la ciencia ficción,

${ }^{2}$ Esta línea de investigación y base teórica nos ha permitido estudiar también la escritura narrativa del escritor y crítico venezolano Miguel Gomes. Al respecto, remitimos a nuestro trabajo "La cartografía del ADN de Viudos, sirenas y libertinos de Miguel Gomes” (2010: 113-124). 
no significa que su impacto sea inferior. En todo caso, se relaciona con el debilitamiento de la literatura contemporánea (Steiner, 2000: 239).

Sin embargo, nos parece que el empleo de la noción de ADN y su uso transdisciplinario viene de antes, pues la aparición del modelo molecular de la doble hélice de ADN, expuesto por Watson y Crick el 25 de abril de 1953 en la revista científica Nature, afectó a todas las áreas de la sociedad. Watson y Crick afirmaron: "We wish to put forward a radically different structure for the salt of deoxyribose nucleic acid. This structure has two helical chains each coiled round the same axis" (1953: 737-738). Después de esto, como señala Steiner, la molécula del ADN pasó a expresar las preocupaciones sobre las implicaciones de la "revolución genética" y comenzó a ser abordada como metáfora tanto para estudiosos de las ciencias puras como de las humanidades, lo cual ha permitido conocer su estructura y funcionamiento. De hecho, Martin Kemp, profesor de historia del Arte en la Universidad de Oxford, definió al ADN como la 'Mona Lisa de la ciencia', en tanto:

ninguna molécula en la historia de la ciencia ha alcanzado el estatus de ícono de la doble hélice del ADN. Su imagen se ha impreso en todos los aspectos de la sociedad, de la ciencia, arte, música, cine, arquitectura y publicidad. Esta revisión de la Mona Lisa de la ciencia examina la evolución de su forma en las manos de la ciencia y el arte (Kemp, 2003: 416-420).

En relación a esto, hay dos trabajos fundamentales para realizar una síntesis de la divulgación del concepto $\mathrm{ADN}$, nos referimos a los artículos de Sergi Cortiñas Rovira "La divulgación de la molécula de ADN" ( 2005: 7884) y "Las metáforas del ADN: una revisión de los procesos divulgativos" -extracto de una tesis doctoral (2008: 4). Cortiñas Rovira, Licenciado en biología y Doctor en ciencias sociales, revisó de forma sistemática la literatura elemental de la divulgación del $\mathrm{ADN}$, primordialmente del ámbito anglosajón, desde donde provienen los científicos y divulgadores más influyentes del siglo XX, como F. Crick, J. Watson, R. Dawkins, G. Gamow, C. Sagan, S. J. Gould, entre otros.

A modo de síntesis, Cortiñas expone el panorama entusiasta frente a la metáfora del ADN en el siglo XX. Leemos:

Los artistas de las corrientes más vanguardistas del siglo XX recibieron con entusiasmo la estructura descrita por Watson y Crick. Uno de los más destacados admiradores de la molécula fue el pintor Salvador Dalí. El artista 
catalán, que tuvo un interés constante por los avances científicos en todas las disciplinas, utilizó la estructura del ADN en numerosas obras pictóricas, como Galacidalacidesoxyribonucleicacid, La escalera de Jacob, La estructura del ADN, Árabes aciddesoxiribonucleics, Paisaje de mariposa o El gran masturbador en paisaje surrealista con $A D N$. Muchos otros pintores, escultores y arquitectos hicieron lo mismo y aprovecharon la elegancia de formas y proporciones de la molécula para tomarla como tema de expresión. Por ejemplo, el artista Roger Berry erigió una gran escultura (Retrato del $A D N$ ) en la sede de la Universidad de California y el arquitecto Charles Jencks creó otra escultura (Spirals Time) que se encuentra en el jardín del Cold Spring Harbour Laboratory de Nueva York (Cortiñas Rovira, 2008: 4).

Así, también, en los estudios literarios, encontramos la utilización de la noción de $\mathrm{ADN}$ en uno de los trabajos del volumen de acercamientos transdisciplinarios a la obra de Jorge Luis Borges editado por Alfonso de Toro Jorge Luis Borges: Ciencia y filosofía (2007); específicamente, en el artículo de Elmar Schenkel "Chimeras in the library. Jorge Luis Borges and genetics" (Toro, 2007: 75-80).

Por nuestra parte, optamos por ocupar la metáfora del ADN desde la perspectiva de la experimentación y la creatividad relacionada con Germán Marín, ya que como afirma Cortiñas Rovira:

El ADN esconde el "secreto de la vida", tal como Crick y Watson anunciaron el 28 de febrero de 1953 a la concurrencia del pub "The Eagle", en Cambridge, cuando celebraban el descubrimiento de la estructura. Los sustantivos secreto, código y los verbos descodificar, descifrar siempre han ido vinculados a la molécula, convertida de esta manera en un símbolo para adentrarse en aquello que permanece oscuro, incomprensible y oculto. De hecho, el misterio que ha rodeado el $\mathrm{ADN}$ ha sido de forma parecida un motor visible para su penetración en la sociedad (Cortiñas Rovira, 2008: 4).

De esta manera, respaldamos la definición de metáfora como una forma de pensamiento que permite comprender "un hecho en términos de otro más accesible y conocido (González y Llinás, 2004: 367). Así, específicamente, entenderemos el concepto de ADN, en la trilogía Hdaf, como una metáfora compleja y misteriosa, con múltiples significados, utilizados por científicos y críticos, que convergen en el devenir de un origen de la vida y la escritura en un constante entrecruzamiento de cadenas inacabadas y extrañas.

En primer lugar, constatamos la metáfora $\mathrm{ADN}=$ doble espiral, en tanto 
Watson, en su libro Biología molecular del gen (2008), señala: "la característica más importante del DNA es que suele estar compuesto por dos cadenas de polinucleótidos enroscadas una alrededor de la otra en forma de una doble hélice" (Watson, 2008: 108). Así, el ADN es una molécula flexible que puede ajustarse a los cambios oportunos cuando las dos cadenas se enroscan una alrededor de la otra. Metafóricamente, el proceso de escritura de Marín trabaja en base a diversos planos fundamentales que se entrecruzan con cierta flexibilidad narrativa, como pasado y presente, ficción y realidad, autor y narrador, etc. Esto crea la idea de fragmentos ambiguos, confusos e indescifrables que se asocia con la noción de la diferencia, que Derrida expone en su libro Papel máquina (2003), en tanto es la articulación en la historia de la vida, como "programa en el sentido de la cibernética, pero esta sólo es inteligible a partes de una historia de las posibilidades de la huella como unidad de un doble movimiento de protensión y retención. Este movimiento desborda ampliamente las posibilidades de la 'conciencia intencional'”. (Derrida, 2003: 111).

En segundo lugar, la metáfora $\mathrm{ADN}=$ origen, en tanto se presenta como el ácido desoxirribonucleico que permite a un ser humano transmitir información genética de una generación de células a la siguiente y originar un nuevo organismo ${ }^{3}$. En el caso de Marín, su escritura es una doble búsqueda, a través de la memoria y la imaginación. Por un lado, para reconstruir el origen de su tronco genealógico dispersado en líneas de fugas a modo de 'ajuste de cuentas', razón por la cual la trilogía se llama Historia de una absolución familiar; por otro lado, una búsqueda del origen de su escritura, la cual se origina misteriosa y contradictoriamente por diversas razones, entre las que se encuentra: el desgano, el aburrimiento, el placer, la inquietud, etc.

Específicamente, en la segunda búsqueda observamos que en el concepto

\footnotetext{
${ }^{3}$ No obstante, hay que hacer notar que todavía el origen del ADN es discutible entre los científicos. La revista Science destacó que más de trescientos científicos, entre ellos tres premios Nobel, concluyeron que la vida se originó gracias a las moléculas de ADN y ARN en la XI Conferencia Mundial sobre el Origen de la Vida, celebrada en Francia en julio de 1996. Sin embargo, los expertos no lograron resolver el misterio de cómo aquéllas surgieron por primera vez y cómo evolucionaron en células de autorreproducción (Science, 1996, pp. 870 - 872). Por otra parte, el biofísico alemán Bernd-Olaf Küppers sostuvo que: "claramente, el problema del origen de la vida equivale básicamente al problema del origen de la información biológica" (Küppers, 1990: 170-172). Richard Dawkins enunció la idea de inmortalidad al afirmar al ADN como "una espiral inmortal" en tanto, su invariabilidad a través de las generaciones de individuos que la transmiten. Y el capítulo tres, "Las espirales inmortales", de su libro El gen egoista, señaló: "Un mono es una máquina que mantiene los genes en los árboles, un pez es una máquina que mantiene los genes en el agua, hay incluso un pequeño gusano que preserva los genes en esteras de la cerveza alemana. ADN trabaja en formas misteriosas" (Dawkins, 1993: 21).
} 
de 'origen' hay una asociación entre los elementos principales: 'vida' y 'escritura' en la obra de Marín, llamada 'literatura escribivida', por él mismo, ya que ambos concatenados crean devenires de una búsqueda inmanente, pero que finalmente bosqueja el 'misterio' del origen, que lo llevará más tarde, en actos de desesperanza, en algunos fragmentos de la trilogía, a reconocer que está en un círculo vicioso, en el cual mientras más avanza, más se dirige hacia un origen. Así, el libro se revela, en una primera instancia, como una confidencia de su destino personal, pero que, en segunda instancia, escapa a los propósitos del autor, quien pretendía escribir un libro imaginario dedicado a Salvador Allende. Este proceso está ligado a una especie de metafísica de la escritura, por lo cual reconocerá la presencia de 'algo más allá de lo físico' que lo lleva a escribir, (re)escribir y (des)escribir los sucesos narrados sin poder controlar ese deseo. Lo anterior podemos asociarlo con la metáfora de $\mathrm{ADN}=$ escalera, referida tanto a la escritura que avanza y retrocede, donde los episodios son peldaños similares a otro, que para subir tiene que retroceder un poco.

Así, desde estos adelantos teóricos y críticos, leemos la narrativa mariniana con una noción de la genética, en tanto acercamos el concepto de "literatura escribivida", en términos metafóricos, al concepto de ADN, basándonos en la forma de sus estructuras y en la función específica de lo inacabado, ya que ambos conceptos referidos -escritura y vida-como cuerpos -uno textual y el otro biológico- transmiten información independiente en sus diferentes componentes, pero conservan rasgos previos que permiten entender las nuevas unidades creadas. Así, Hdaf es un mapa literario, en secuencias únicas narrativas al igual que mapa del genoma humano, donde el ADN del libro lleva la información necesaria para realizar una replicación; es decir, una repetición, nunca igual, de la historia familiar de Germán Marín y de los escenarios privados y públicos de una familia y de una colectividad chileno-italiana.

\section{LA METÁFORA DE LA ESPIRAL DEL ADN}

$$
\text { "La palabra se podía convertir en sangre” (G.M.) }
$$

Los tres volúmenes de la trilogía Hdaf de Germán Marín estaban preparados para ser publicados originalmente en un solo tomo. Por tal razón, el lector encuentra una disposición de los procesos narrativos similar en los tres libros: la historia familiar, un diario de vida del autor y las notas de su 
alter ego Venzano Torres. Esto, a pesar de su publicación distante en varios años.

Además, el prólogo de cada volumen, a cargo de su alter ego, funciona como un texto de crítica literaria donde se plantea una redefinición de la tarea de escribir en el proceso de gestación de la novela. Venzano Torres considera el libro Círculo vicioso como una obra que aún está escribiéndose y: "ese carácter inacabado que posee, provisorio, tentativo, fragmentario, errático...le confiere a dicha lectura las mismas oscilaciones que tuvo para el autor la elaboración del texto" (Marín, 1994: 12). De la misma manera, en Las cien águilas, Venzano Torres caracteriza la escritura como una espiral sin fin que funciona, en forma de relevo, en una línea narrativa consanguínea, que comienza narrando su padre Raúl Marín y quien, posteriormente, le entrega la palabra a su hijo Germán. Leemos: "Bajo la espiral que dibuja la novela no hay fin" (1997: 12). Finalmente, en el último tomo de la trilogía, $L a$ ola muerta, Venzano Torres reafirma lo dicho en los volúmenes anteriores, confirmando la continuidad del proyecto literario y la idea de lo "inacabado" en la escritura, en tanto búsqueda de sí misma que no puede terminar. Así señala: "sujeta al devenir real, es una obra anclada en cierto pasado que nunca termina al ensamblarse en un tiempo común en los distintos planos del relato" (2005: 11).

Germán Marín utiliza una escritura que incluye una noción sanguínea, relacionada con el concepto de "literatura escribivida", la fusión de los términos 'escritura' y 'vida'. Ambos funcionan en su obra como experiencias de su vida a través de la vía de la conciencia, en un proceso de escritura que se complejiza hasta convertir la literatura en una reflexión sobre sí misma: "que mira siempre hacia atrás, en un permanente viaje inmóvil, mientras avanza en la narración de sí misma" (1997: 142), "curva sin extremo de la literatura, del origen y final de un mismo cuerpo" (1997: 18).

Así, en términos marinianos, la escritura se convertirá en "carne de literatura", en tanto su "cuerpo" es el eje de su escritura, contada desde una mirada nublada -que da espacio a la imaginación- hacia sus orígenes y hacia sí mismo, con la posibilidad de su autoaniquilación y de su lenguaje. Por esto, la intransitividad de su literatura lo lleva a afirmar: "como zorro o lobo que se amputa la pierna para liberarse del cepo, terminaré devorándome" (Marín, 1997: 33).

Por lo expuesto, postulamos que Germán Marín conforma una metáfora del ADN de la escritura, en tanto su obra puede calificarse como 'un libro de vida' y con un doble carácter, en tanto espiral que funciona, por una parte, como una búsqueda del origen de su escritura, que no puede descifrar en su 
diario de vida, y, por otra parte, como la búsqueda del origen de su historia personal y de su familia en la historia narrada. Ambas búsquedas convergen desde un pasado eternizado que no termina, porque se entrecruza con el presente efímero e incierto que no se define en su propia vida-escritura. Citamos:

\section{En Círculo vicioso:}

La fuerza que lo lleva a recorrer el mismo círculo (Marín, 1994: 255)

La novela es una indagación que siempre deja enigmas (Marín, 1994: 364).

\section{En Las cien águilas:}

Era un texto que generándose a sí mismo en una multiplicación infinita, sin la urgencia de publicación, podía quedar en la sombra (Marín, 1997: 11).

Si cada aspecto del día de ayer no hubiera estado engravado el uno al otro en ese orden secreto que posee la vida, jamás habría llegado a toparme con ella orientado mediante esa fuerza que por comodidad llamamos azar (Marín, 1997: 347).

\section{En La ola muerta:}

Me resulta curioso que, mientras vivo el presente, el interés de mi parte está puesto en resucitar un pasado que, sepultado entre sus escombros, trato de ajustarlo a un orden que permita su relato (Marín, 2005: 24).

Trataré de resucitar entre los vivos, dispuesto a salir adelante palabra tras palabra, en unas frases largas como pasillos que ojalá me lleven lejos, hacia el pasado, que siempre es el inicio (Marín, 2005: 270).

Específicamente, los dos tipos de textos principales e intercalados en los tres volúmenes de la trilogía y que representan dos planos temporales: la historia narrada (pasado) y diario de vida del autor (presente) dialogan en la materia narrativa cuando Germán Marín entrecruza la ficción y la realidad. Por una parte, hay una búsqueda incesante hacia el pasado en la línea familiar en la historia narrada, utilizando como recurso principal una memoria 
ficcionalizada; por otra, está el diario de vida del autor, donde el autor cuenta el proceso de gestación de sus novelas, incorporando las vicisitudes de su vida cotidiana, comentarios y análisis sobre su propia escritura y la de otros autores. A través de Venzano Torres se interroga sobre la función de la literatura y la escritura: "el autor escribe desde las dudas del oficio, frente a la duda mayor que representa la interrogación personal para qué sirve escribir" (Marín 1997: 13).

De esta manera, nos centraremos en la búsqueda del ADN de su escritura definida por el propio narrador como una "escritura heurística, capaz de verse a sí misma como resultado de su propia crisis" (Marín, 1997: 162). A esto, Venzano Torres agrega que la escritura está cargada de fugas y repliegues, que aparecen como discordantes con la fluidez narrativa, al presentar un carácter provisional, jugando, paradójicamente, con la otra búsqueda, la que trata de reconstruir su historia familiar. Leemos: "las vidas de unos y otros quizá resultan demasiado metafóricas en el transcurso que he trazado" (Marín, 1997: 148). En relación a esto, cuando el narrador asume que su escritura se centra en una búsqueda intransitiva entra en crisis con su complejo proyecto literario y deviene distintos animales. Por ejemplo: cangrejo cuando señala: "escribir y su envés reescribir, era para él existir igual que el cangrejo que, al retroceder, está avanzando"(Marín, 1997: 12); crustáceo: "inseguro y lento como un crustáceo, tiendo por naturaleza a avanzar y retroceder en la escritura"(Marín, 1994: 72); hipopótamo: "me he transformado en un hipopótamo, aunque me salva en parte el hecho que, a diferencia de este mamífero, mis ojos pueden mirar no sólo hacia adelante" (Marín, 1994: 248) y pájaro: "al pájaro fantástico que sólo volaba para atrás, obsesionado por el pasado" (Marín, 1994: 240). Esto último es una referencia a Goofusbird del libro de Los seres imaginarios de Borges, donde se señala que: "es el pájaro que construye el nido al revés y vuela para atrás, porque no importa adónde va, sino dónde estuvo" (Borges, 2005: 240).

De este modo, podemos relacionar que aquel vaivén de la escritura mariniana se corresponde con la idea planteada por Foucault en Las palabras y las cosas (1997), donde señala: "La tarea infinita de pensar el origen, lo más cerca y lo más lejos de sí. El hombre está disperso en el interior de un poder, su propio ser" (Foucault, 1997: 325), así como "el lenguaje lleva en sí mismo su principio interior de proliferación" (Foucault, 1997: 48). Por esto, Marín posibilita pensar el misterio del origen de su escritura a través de la metáfora de una cebolla, constituida por capas, que al ir desgajándola permitiría una búsqueda para descifrar el tramado de la construcción: 
El misterio de esas capas hace que comience a retirar una y después otra, a la búsqueda de descifrar el tramado de su construcción, sin que por esto pierda la figura que lo conforma en su tierna redondez. En el centro de ella debe estar, como imagino, el germen de su nacimiento, mientras prosigo la labor de desgaje, amparado por la última luz de la estación, pelando las faldas que la cubren bajo un olor mordiente. A pesar del ensimismamiento, me he dado cuenta que al dejar los últimos restos, quedare sin nada entre los dedos, desaparecida la cebolla, en la maravilla semidivina de su composición, en cada vuelta que la vestía con su seda transparente. Ella también, a pesar del privilegio de su creación, en la obra sin fin de su bulbo, esconde la lágrima de una nada (Marín, 1997: 141).

Por ello, la escritura inconclusa en la trilogía $H d a f$ se fragmenta, ramifica, avanza y retrocede. Así, en un constante movimiento, el control del proceso de escritura resulta imposible para el autor, ya que es una tarea extrema que le provoca inseguridad cuando enfrenta el problema de escribir y lo lleva a comparar la escritura con una escalera, donde "los sucesos son peldaños que no se sabe si sube o baja" (Marín, 1994: 160); es decir, estamos frente a $\mathrm{ADN}$, la palabra errante y seductora, siempre en movimiento, que no empieza ni acaba. De hecho, Germán Marín es fascinado por la escritura al implicarse más en el libro y en el texto central, insertando fragmentos de su diario de vida en la novela: "estas notas personales no deberían ir aquí, pero a través de ellas siento que me implico aún más en el libro" (1994: 45). Así, la escritura pasa a formar parte de la vida y, como escribe Blanchot en La escritura del desastre:

Los fragmentos se escriben como separaciones no cumplidas: lo que tienen de incompleto, de insuficiente, obra de decepción, es su deriva, el indicio de que, ni unificables, ni consistentes, dejan esparcirse señales con las cuales el pensamiento, al declinar y declinarse, está figurando unos conjuntos furtivos, los cuales, ficticiamente, abren y cierran la ausencia de conjunto, sin que, fascinada definitivamente, se detenga en ella, siempre relevada por la vigilia que no se interrumpe (Blanchot, 1990: 55).

Tal vez, por esta razón, el autor opta por analizar la lengua y hacer un uso consciente de un lenguaje menor y situarse en los márgenes, donde puede jugar más libremente con la escritura y el lenguaje. En términos similares, George Steiner señala que el acto lingüístico permite descubrir el lenguaje "no como un sistema estático preestablecido sino como energía creadora" 
(Steiner, 2000: 190). Del mismo modo, Marín percibe su lenguaje: "siendo penetrado lentamente casi sin fragmentos, por palabras que consideraba ajenas y distintas a las que traía a pesar de provenir del mismo tronco. No me parece mal, en esta situación fronteriza ante el español, quedar con un pie en cada orilla del idioma" (Marín, 1994: 117).

Además vemos, en la cita anterior, que Marín reconoce que está dentro de un contexto en el cual su lenguaje se ve influenciado. Para él la noción de literatura es una sola historia ya contada y que se repite indefinidamente (Marín, 1999: 151-152). Esto se relaciona con las ideas de Foucault y su libro Las palabras y las cosas en tanto "el hombre siempre puede pensar lo que para él es válido como origen sólo sobre un fondo de algo ya nacido. Este no es para él el comienzo...el origen es más bien la manera en que el hombre en general, todo hombre sea el que fuese, se articula sobre lo ya iniciado del trabajo, de la vida y del lenguaje" (Foucault, 1997: 322).

De esta manera, el hombre es definido como un relevo en una red de circulación, donde, en palabras de Foucault, el autor descubriría que:

El hombre sólo se descubre ligado a una historicidad ya hecha: nunca es contemporáneo de este origen que se esboza a través del tiempo de las cosas sustrayéndolas a él, cuando trata de definirse como ser vivo, sólo descubre su propio comienzo sobre el fondo de una vida que se inició mucho antes que él, cuando trata de retomarse como ser que trabaja, sólo saca a la luz las formas más rudimentarias en el interior de un tiempo y de un espacio humanos ya institucionalizados, ya dominados por la sociedad (Foucault, 1997: 321).

Así, Marín, cuando está en las orillas del lenguaje, comienza incrédulo una escritura indagatoria sobre un pasado que es un eterno retorno, restaurado en forma de memoria revivificada a través de la imaginación para tratar reconstruir las posibles conexiones que le permitan llegar al origen-respuesta de su inquietud. Foucault, citado por Ángel Gabilondo en el prólogo de De lenguaje y literatura, reconoce en Blanchot 'la memoria sin recuerdo', plantea: "la memoria sin recuerdo, una especie de niebla que reenvía permanentemente a la memoria, una memoria sobre la memoria y cada memoria borrando todo recuerdo, y esto indefinidamente... [agregado por Gabilondo, lo siguiente] la memoria seca el recuerdo, pero las palabras sangran" (Foucault, 1996: 47).

Notamos, en el proceso de escritura de las novelas de Marín, en términos de Foucault que "el lenguaje no cesa de repetirse" (Foucault, 1996: 86) 
y que "la literatura es un lenguaje al infinito, que le permite hablar de sí misma hasta el infinito" (Foucault, 1996: 81). Así, la literatura mariniana se reduplica a sí misma, interminablemente, hacia la vida del autor, su linaje y su compleja relación con la escritura, yendo hacia un espacio misterioso que lo atrapa en un tiempo ahistórico. Leemos: "la escritura tiene repliegues ocultos" (Marín, 1994: 329). Otras citas: "las palabras nunca traducen donde se quiere llegar, no revelan sino, que más bien ocultan el camino" (Marín, 1997: 258); "escribir desde un pasado reconstruido es hacerse prisionero de uno mismo, de las palabras que no progresan, al menos en el sentido de las manecillas del reloj" (Marín, 2005: 130). Igualmente, nos percatamos que Marín utiliza una escritura que se recurva sobre sí misma. Desde el título del primer tomo de la trilogía, Círculo vicioso, se perciben formas circulares hasta la portada de La ola muerta, donde una gran ola recoge unas pequeñas embarcaciones que, al igual que el final del libro, reúne distintos personajes de los tres volúmenes, regresando al punto de partida y desapareciendo misteriosamente. Leemos:

Dispuestos a llegar al océano, cada vez más cercano, miraban cómo éste se iba ensanchando en un gran abrazo que se confundía con la noche y, en esa misma medida, la escasa iluminación del poblado de pescadores no mitigaba la inmensidad que se abría negra en la pantalla (Marín, 2005: 356).

De este modo, podemos incluir una cita de Blanchot en su libro La escritura del desastre (1990), donde señala: "No hay origen, si origen supone una presencia original. Siempre pasado, desde ahora pasado, algo que pasó sin estar presente, tal es lo inmemorial brindado por el olvido, que dice: "todo comienzo es recomienzo" (Blanchot, 1990: 102). En tanto que Marín afirma en La ola muerta: "concluía que todo llevaba a la repetición, a transitar siempre el mismo camino" (Marín, 2005: 58).

Esto, relacionado también con las ideas foucaultianas respecto a la noción de lenguaje, puede trasladarse al concepto de escritura como una puesta en escena, donde:

Un sistema arbitrario de signos debe permitir el análisis de las cosas en sus elementos más simples; debe descomponer hasta llegar al origen; pero debe mostrar también cómo son posibles las combinaciones de estos elementos y permitir la génesis ideal de la complejidad de las cosas (Foucault, 1997: $68)$. 
En síntesis, basándonos en las reflexiones de estos teóricos del lenguaje y de la literatura, analizaremos distintas combinaciones utilizadas en la escritura de Germán Marín a modo de análisis funcional y específico en la Hdaf.

\section{LOS DOBLES EN ESPIRAL: MEMORIA E IMAGINACIÓN}

"La memoria, a veces cuenta mentiras" (G.M.)

Germán Marín, continuamente, deja evidencia, fallas, correcciones y tachaduras del proceso de escritura en los tres libros, conectándose con la idea enunciada por Ricardo Piglia en Crítica y ficción "escribir es corregir" (Piglia, 2000: 61), hasta el punto que genera una lectura utópica, en tanto se lee como si fuera otro para corregirse sin terminar jamás. Leamos un lugar específico en Las cien águilas:

\section{3, 9 de agosto}

El carácter provisional de estas páginas me da confianza de retroceder, de deliberar, de corregir, de sospechar acerca de lo que escribo, pues, hasta el momento, de acuerdo al libro anterior, he sido mi padre al hablar, he sido tú, llevado por el artificio de constituirme en el oidor de los hechos narrados (Marín, 1997: 17).

Foucault, en su libro De lenguaje y literatura (1996), establece una relación entre los conceptos lenguaje, obra y literatura. El primero, entendido como un "murmullo de todo lo que se pronuncia" (Foucault, 1996: 64), el segundo, definido como un espacio que retiene el "derrame del murmullo" (Foucault, 1996: 64), actuando como un simulacro, en tanto creación de un proceso subjetivo y una experiencia lúdica del lenguaje que llena un vacío (lo no escrito ni dicho). El tercero, propuesto como el "vértice de un triángulo por el que pasa la relación del lenguaje con la obra y de la obra con el lenguaje" (Foucault, 1996: 64).

A partir de estos conceptos, podemos establecer en Hdaf un acercamiento hacia la figura del "doble", presente desde la noción de la literatura, especie de doble de una obra, con quien nunca se encuentra, pues ésta es la distancia entre lenguaje y literatura.

Como señala Foucault, "la literatura es un lenguaje al infinito, que le permite hablar de sí misma hasta el infinito" (Foucault, 1996: 81), ya que se 
reduplica a sí misma interminablemente a través de un lenguaje ilimitado, inmóvil y fracturado que implica una experiencia cruzado de sí mismo. En relación con esta afirmación, Marín entrega una referencia bibliográfica de Foucault y señala:

La literatura quizá sólo sea una historia ya contada que se vuelve a repetir una y otra vez. Al corregir más adelante estas líneas provisorias, dejadas un poco entre paréntesis, tal vez sea necesario emplear un tono aburrido, desgajado, como si se tratara de una cierta historia ya relatada (Marín, 1997: 151).

Recordemos que, cuando la retórica desaparece en el siglo XVIII, la literatura se encarga de definir los signos y juegos de sí misma. Así, para Foucault, "la literatura es un lenguaje a la vez únicamente único y sometido a la ley del doble" (Foucault, 1996: 72), por cuanto ella, por una parte, cuenta una historia determinada y, por otra, muestra y hace visible lo que es ella misma. Agrega: "la obra va sin cesar por delante de la literatura, la literatura es esa especie de doble que se pasea ante la obra, la obra no la reconoce nunca, la cruza, no obstante, sin detenerse" (Foucault, 1996: 73).

Por tal razón, la escritura funciona como un llamado fascinante de ecos dentro de la obra, cuya habla llama a la literatura a crearse como un espacio donde:

La obra le hace señas a la literatura; ¿qué quiere decir esto? Quiere decir que la obra llama a la literatura, que le da garantías, que se impone a sí misma cierto número de marcas que le muestran a sí y a las demás que es efectivamente literatura. A esos signos, reales, por los cuales cada palabra, cada frase indican que pertenecen a la literatura, la crítica reciente, desde Roland Barthes, los llama la escritura. Esta escritura nace de cualquier obra, en cierto modo, una pequeña representación, algo así como un modelo concreto de la literatura...se puede decir que cualquier obra dice no solamente lo que dice, su historia, su fábula, sino, además, dice lo que es la literatura (Foucault, 1996: 72).

Este desdoblamiento de la literatura se presenta en la escritura mariniana, efectivamente, como un des-encuentro entre la obra real y la literatura de carne y hueso, en tanto, la primera es un espacio del espejo que simula a la segunda que no puede ser captada. Así, se explica el miedo que Germán 
Marín tiene, a veces, cuando entra en el espacio de la literatura y pierde el control: "no deja de provocarme cierto miedo cada vez que retomo la novela a fin de proseguir en la tarea de su escritura. Siento frente a mí una obscuridad que, aparte de la zozobra de tener que atravesarla, desconozco dónde me llevará" (Marín, 1997: 39).

Por tanto, de la misma forma como señala Ángel Gabilondo en el prólogo del libro De lenguaje y literatura (1996) de Michel Foucault, la vida de Germán Marín es interrumpida por la escritura de su obra, la cual abre su propio espacio, donde no pueden convivir ambas y sólo puede procurar el saber del retorno a través de "las aventuras de las voces y de los discursos encabalgados, impugnándose unos a otros, las que llevan la insurrección silenciosa de las palabras" (Foucault, 1996: 47).

De la misma manera, Blanchot afirma en El libro que vendrá: "la literatura empieza con la escritura. La escritura es el conjunto de ritos, el ceremonial evidente o discreto por donde, independientemente de lo que se desea expresar y de la manera como se expresa, se anuncia ese acontecimiento según el cual lo que se escribe pertenece a la literatura, el que lo lee, lee literatura" (Blanchot, 1992b: 231) y donde escribir es negarse a escribir. En palabras de Marín, "si dejara de escribir, doblegado por el silencio, no tendría nada más que hacer y conocería hasta las heces la repetición cotidiana” (Marín, 1997: 124).

Por esto, una de las técnicas narrativas mariniana es la creación de un alter ego, Venzano Torres, con quien Germán Marín establece un encuentro epistolar de exiliados, que posibilita un diálogo entre la memoria y la imaginación, con el fin de recuperar un pasado irrecuperable durante el período de gestación de la novela. Además, Venzano Torres se hace cargo del cuidado de la edición de sus libros y escribe las notas bibliográficas al final de cada capítulo, a excepción de La ola muerta, donde aparecen todas las notas reunidas al final de la obra.

En la trilogía $H d a f$, la figura de este 'otro' ficticio aparece en relación con la figura del escribiviente, quien necesita un interlocutor cuando es "emboscado en una primera persona ausente, lectora y crítica de sí misma con la necesidad de tener un interlocutor" (Marín, 1997: 17). El encuentro entre ambos permite un intercambio entre los planos de la verdad y la ficción o, en otras palabras, entre la memoria y la imaginación, donde la escritura mariniana trabaja con el primero para construir un discurso que no es verdadero ni falso y que no pretende serlo. Más bien, el escritor ficcionaliza la memoria a modo de un juego de dobles. Notamos: "Conjeturo, basado en 
ciertas teorías sobre el doble, que en estos momentos un hombre nacido el mismo día que yo, quizá de nombre Venzano Torres, transitaba por esa misma calle dirigiendo sus pasos a la Biblioteca Nacional" (Marín, 1997: 112,113).

Lo anterior es producto de la fascinación que provoca en el escritor la teoría de los dobles, la cual le permite replegarse en otros: "Eran unas simulaciones ante el doble que me atraían por su extrañeza" (Marín, 1997: 317). De esta manera, el desdoblamiento del autor en figuras ficticias crea una doble curva entrelazada, en tanto desvirtúa 'la memoria' a través de 'la imaginación’ mientras avanza la historia. Así, es imposible saber cuándo la escritura mariniana pertenece a uno de los planos mencionados, incluyendo las referencias bibliográficas entregadas en las notas. Incluso, el autor plantea desencuentros entre las figuras de los dobles, con el fin de establecer un vaivén constante en la escritura y no establecer un dogma, sino un juego de máscaras. Citamos: "Tal como me señala Venzano Torres en su carta última, dentro de una correspondencia que se ha vuelto discontinua, duda no sin razón de que este año yo terminé el presente y último tomo de la trilogía" (Marín, 2005: 130). También: "he recibido unas líneas de Venzano Torres, escritas desde su México consuetudinario, en que me acusa de haber abandonado este tomo de la trilogía. Nada le he dicho que prosigo, bajo el silencio un tanto culpable de quien no está seguro adónde va ni para qué lo hace" (Marín, 2005: 117).

Ahora bien, el constante diálogo narrativo entre Germán Marín y Venzano Torres en los tres volúmenes de la trilogía $H d a f$ se presenta no solamente en los dos textos fundamentales La historia narrada y el diario de vida del autor, sino también en el discurso crítico, en los epígrafes y en los prólogos, a cargo de Venzano Torres, donde éste se desplaza hacia el lado de la realidad para establecerse como un detective, en términos piglianos, en tanto investigador que "trata de hacer oír su voz como una voz verdadera" (Piglia, 2000: 13) y que trata su trabajo crítico como un acto de escritura que pretende "borrar la incertidumbre que define a la ficción" (Piglia, 2000: 13) y gracias al uso de ésta "el ejercicio de la ficción se convierte en precrítica, en documento investigatorio, mechado por los pasajes del Diario del escritor y, también, vaya, por las notas apólogas del preparador de la edición" (Marín, 1997: 12). No obstante, Venzano Torres es un personaje ficticio de la literatura mariniana a través de, por ejemplo, el epígrafe del prólogo de cada volumen. Esto, a pesar de la distancia de dieciocho años entre el inicio de la publicación del primer tomo y el último. 
En busca del ADN de la escritura en Historia de una absolución familiar de Germán Marín / M. Fuentes LEAL

Leemos:

Círculo vicioso (septiembre de 1987)

Detesto tu franqueza. Por ventura ¿te pedí que dijeras la verdad? (11)

Las cien águilas (octubre 1994)

Y no es que lo engañara. Yo, simplemente, contribuía a dar forma a sus ilusiones (11).

La ola muerta (mayo 2005)

Dos los que entre desdichas y locuras aquí hemos llegado (11).

Nótese que es posible trazar una continuidad en forma de diálogo entre Germán Marín (real) y Venzano Torres (imaginario) a un nivel formal del lenguaje, donde hay cierta jerarquía de uno hacia otro evidenciada a través de algunos vocablos: "lo engañara" y "a sus ilusiones". Vemos que el primer sujeto rechaza la verdad e increpa y cuestiona al otro por declararla; sin embargo, éste contesta como si hubiese un mal entendido, puesto que no ha dicho la verdad sino "contribuía a dar forma a las ilusiones" del primero. Por tanto, ambos se sitúan a lado de la 'imaginación' y terminan juntos el pedregoso y trastornado trayecto.

Además de lo expuesto, pensamos que Germán Marín no sólo crea la figura de Venzano Torres como uno de sus dobles, sino que también el personaje homónimo dentro de la obra funciona como un ser 'imaginario' que, en un proceso de enajenación, entremezcla la memoria del autor con la ficción. Leemos: "yo soy otro cuando escribo y ese doble expresa lo que no digo. En cualquier caso, sólo pido que mañana no juzgue la obra ese crítico dominical" (Marín, 1997: 358). Otra cita: "Hubiera al personaje, encarnado por mí, a huir de regreso al país bajo un desarrollo literario quizá barroco" (Marín, 2005: 348).

De ese modo, Marín rechaza el texto limpio de toda incertidumbre, fusionando la vida y la escritura, donde ésta funciona como un salvavidas frente a la vida cotidiana en el exilio: "El que era no podía encontrar mejor solución al tedio de su existencia que esconderse en el que escribía (en la vida), quien a su vez no era más que una caja de resonancia del que hablaba ventricularmente en el relato. Juego de máscaras literarias" (Marín, 1994: 130).

Así, Germán Marín escribe desde su memoria y la escritura se convierte 
en herramienta de sobrevivencia, que lo salva de la realidad monótona para perderse en el espacio abierto y nómade de la literatura, donde puede dialogar con las figuras ficticias por razón del lenguaje infinito de la imaginación, adquiriendo un estilo íntimo y personal ligado a su condición de exiliado. En relación al estilo, Blanchot señala: "sería la parte oscura, ligada a los misterios de la sangre, del instinto, profundidad violenta, densidad de imágenes, lenguaje de la soledad en el que hablan ciegamente las preferencias de nuestro cuerpo, de nuestro deseo" (Blanchot, 1992b: 231).

El estilo de Germán Marín gira en torno, justamente, a los enigmas de la sangre de la familia Marín-Sessa. El personaje homónimo retorna a su raíz constituyente, que a medias es también la del autor, con el fin de indagar el registro personal y familiar del pasado, a través de la escritura, que repite algunos episodios 'reales' e históricos y los altera con recursos de la ficción. Con esto se percibe una constante búsqueda hacia un origen que reescribe experiencias que son re-significadas a través de la ficción. En relación a la idea anterior, Blanchot comenta: "El poema es la profundidad abierta sobre la experiencia que lo hace posible, el extremo movimiento que va de la obra hacia el origen de la obra, la obra misma convertida en la inquieta e infinita búsqueda de su fuente" (Blanchot, 1992b: 222).

Constatamos, por ende, que el personaje Germán Marín percibe tanto el misterio del pasado tanto de su vida como de su escritura; pues a pesar de que ambos son reescritos por él, a través de una escritura provisional, corregida, pulsional y fragmentada, él no logra escapar de la fascinación de hablar sobre el eje de sí mismo y de su escritura. Ese es su ADN. Con respecto a esto, Foucault ha declarado: "El pensamiento moderno está consagrado de un cabo a otro a la gran preocupación del retorno, al cuidado de recomenzar, a esta extraña inquietud que lo hace sentirse obligado a repetir la repetición" (Foucault, 1997: 324). Incluso cuando Marín habla del porvenir de su libro, señala: "El único futuro que visualizo es la novela que estoy escribiendo sin apuro, paso a paso, pero su ejecución es, a la vez, un giro hacia el pasado, donde espero no extraviarme en la maraña de esos días confusos, aunque quizás el enredo ya sucede"(Marín, 2005: 168).

De este modo, planteamos que la indeterminación entre la memoria y la imaginación, producto del entrecruce constante entre ambos recursos, en la trilogía $H d a f$, da origen a la idea de la doble espiral, que al igual que el ADN, no termina ni se desenreda, sino que avanza mientras retrocede, porque, como señala Blanchot en El libro que vendrá:

Pareciera que el tiempo dispersado por una secreta catástrofe interior, deja 
que segmentos del porvenir se hagan vislumbrar en medio del presente o que entren en libre comunicación con el pasado. El tiempo soñado, el tiempo recordado, el tiempo que hubiese podido ser y, por último, el futuro se transforma incesantemente en la presencia radiante del espacio, lugar de expansión de la pura visibilidad (Blanchot, 1992b: 183).

Por ende, para Germán Marín, en relación a Blanchot: "la vigilia no tiene principio ni fin" (Blanchot, 1990: 47), en tanto organiza una red de circulación en la que él está definido como un relevo y, a través del lenguaje, puede crear un universo simbólico en el interior del cual puede construir una obra sinónimo de escritura de un retorno nunca acabado. Leemos: "A la vez ese futuro no sería otra cosa que un pasado también remoto si somos fidedignos" (Marín, 2005: 346-347).

Por lo mismo, cuando finaliza La ola muerta, la novela reúne los planos temporales, pasado y presente, así como memoria e imaginación en un episodio, donde se desvanecen los límites y se cierra la historia familia, conjugando los dos planos anteriores y volviendo, de algún modo, al origen de la historia. Así, para concluir, leemos:

En ese momento me di cuenta de que la cabeza empezaba a pensar por su lado y que yo veía lo que ésta imaginaba como era ese río que, al observar con más atención, resultaba el mismo que aparecía en Circulo vicioso, el Imperial, donde navegaba, como en la novela, el antiguo ferryboat American Boy...el hoy de esa tarde era semejante al ayer de cualquiera otra tarde... así era la película que estaba viendo, cada vez más parecida al escenario que abriera esa novela, escrita hacía varios años (Marín, 2005: 353).

\section{REFERENCIAS}

Blanchot, Maurice. 1990. La escritura del desastre. Caracas: Monte Ávila Editores.

. 1992a. El espacio literario. Buenos Aires: Paidós.

1992b. El libro que vendrá. Caracas: Monte Ávila Editores.

Borges, Jorge Luis. 2005. Los seres imaginarios. Buenos Aires: Emecé editores.

Cortiñas Rovira, Sergi. 2005. "La divulgación de la molécula de ADN", en Revista de la Sociedad Catalana de Quimica 6, pp. 78-84.

. 2008. "Las metáforas del ADN: una revisión de los procesos di- 
vulgativos", en Journal of Science Communication International 7. [En línea] Disponible en http://jcom.sissa.it/archive/07/01/Jcom0701(2008) A02/Jcom0701(2008)A02_es.pdf. (Consulta: 30/10/2010).

Dawkins, Richard. 1993. El gen egoista. Las bases biológicas de nuestra conducta. Barcelona: Salvat Editores, S.A.

Deleuze, Gilles y Guattari, Félix. 1990. Kafka. Por una literatura menor. México D.F.: Era. 1997. Rizoma. Valencia: Pre-textos.

Derrida, Jacques. 2003. Papel máquina. Madrid: Editorial Trotta.

El Mercurio. 1999. "A partir de los escombros". (Entrevista a Germán Marín). 18 de junio, p. 15.

Espinosa, Patricia. 1997. "No hay primera sin segunda", en La Época, 22 de junio, p. 34.

Edwards Renard, Javier. 1997. "El segundo escribiviente", en El Mercurio, 2 agosto, p. 3.

Filebo. 1995. "Los tiempos del Círculo Vicioso", en Las Últimas Noticias, 8 enero, p.14.

Foucault, Michel. 1996. De lenguaje y de literatura. Barcelona: Paidós Ibérica.

1997. Las palabras y las cosas. México: Siglo XXI editores.

Fuentes Leal, Mariela. 2010. "La cartografía del ADN de Viudos, sirenas y libertinos de Miguel Gomes", en Taller de Letras 46, pp. 113-124.

González, María Inés; Llinás, Ester Isabel. 2004. "La metáfora biológica y la práctica científica en Emile Durkheim", en Espacio Abierto: Cuaderno venezolano de Sociología 3, Vol. 13, pp. 367-379.

Guattari, Félix. 1995. "El nuevo paradigma estético”. En Fried Schnitman, Dora (comp) Nuevos paradigmas, cultura y subjetividad. Buenos Aires: Paidós Ibérica, pp. 185-212.

Guattari, Felix. 1996. Las tres ecologias. Valencia: Pre-textos.

Kemp, Martin. 2003. "The Mona Lisa of modern science", en Nature 421, pp. 416-420.

Küppers, Bernd-Olaf. 1990. Information and the Origin of Life. Cambridge: MIT Press.

Lyotard, Jean-Francois. 1984. La condición postmoderna: Informe sobre el conocimiento. Madrid: Cátedra.

Marín, Germán. 1994. Círculo vicioso. Santiago: Editorial Planeta. 1997. Las cien águilas. Santiago: Editorial Planeta. 2005. La ola muerta. Santiago: Editorial Sudamericana. 2008. Discurso en la ceremonia de recepción del Premio Ate- 
nea, Casa del Arte, Universidad de Concepción, 14 de noviembre.

Marks, Camilo. 1996. "En busca del tiempo vivido", en La Epoca, 29 de enero, p. 3.

Matus, Álvaro. 2007. "Soy reaccionario de alma y progresista de vocación”, en Revista de Libros de El Mercurio, 05 de agosto.

Osorio, Daniel. 1997. "Germán Marín: Escribo porque no morí a tiempo", entrevista en La Tercera, 15 de julio, p. 44.

Piglia, Ricardo. 2000. Crítica y ficción. Buenos Aires: Seix Barral.

Pinto, Rodrigo. 2006. "La ola muerta”, en revista El Sábado, de El Mercurio, 18 marzo, p. 7.

Rivera, Angélica. 1997. "Lo imaginario también es real", en Las Ultimas Noticias, 13 junio, p. 32.

Steiner, George. 2000. Extraterritorial. Ensayos sobre literatura y la revolución del lenguaje. Buenos Aires: Adriana Hidalgo.

Todorov, Tzvetan. 1987. La notion de littérature. Paris: Editions Du Seuil.

Toro, Alfonso de. 2007. Jorge Luis Borges: Ciencia y Filosofía. Georg Olms Verlag AG, Hildesheim.

Watson, J.D. y Crick, F.H.C. 1953. "A structure for Deoxyribose Nucleic Acid", en Nature 171, pp. 737-738.

Watson, James. 2008. Biología molecular del gen. Buenos Aires: Médica Panamericana. 